\title{
Are Consumers More Loyal to National Brands than to Private Labels?
}

FABIAN BERGÈS, DANIEL HASSAN AND SYLVETTE MONIER-DILHAN 


\title{
Are consumers more loyal to national brands than to private labels?
}

\author{
Fabian Bergès, Toulouse School of Economics (GREMAQ-INRA and IDEI) \\ Daniel Hassan, Toulouse School of Economics (GREMAQ-INRA) \\ Sylvette Monier-Dilhan, Toulouse School of Economics (GREMAQ-INRA) \\ UMR GREMAQ-INRA - Bâtiment F \\ 21 Allée de BRIENNE \\ F-31000 Toulouse \\ FRANCE
}

\begin{abstract}
:
The evolution of private labels has been linked to the strategy adopted by the retail industry to increase competition with national brands in terms of quality. Since the early 2000s, retailers have upgraded their store brands by introducing high-quality products along with "me too" retail products. The aim of this study is to analyze consumer perception of both types of private labels ("me-too" and high quality products) compared to national brands. We deal with three staple goods offered by three mass retail companies. We show that consumer demand for "metoo" private labels is as elastic as for national brands. This result indicates that such private labels are now considered as leading brands in terms of characteristics. However, on the high quality market, consumers are more sensitive to the price of private labels, indicating a lesser attachment to these brand names.
\end{abstract}

Keywords: National Brands, Private Labels, Demand Elasticity, Competition.

JEL: D12, L81, Q13

\section{Correspondence:}

Fabian BERGÈS

UMR GREMAQ (MA 103)

21 Allées de BRIENNE

F-31000 Toulouse

FRANCE

Mail: Fabian.Berges@ toulouse.inra.fr

Tel: $\quad+33.5 .61 .12 .85 .80$

Fax: $\quad+33.5 .61 .22 .55 .63$ 


\section{Introduction}

The development of retailers' brands in France, commonly named Private Labels (PLs), remains 30 years after their creation a topical phenomenon. A recent study emphasizes that their development is continuing (Moati, 2008). These PLs currently represent $29 \%$ in value of the sales of consumer products by the mass retail industry, and $24 \%$ in volume. ${ }^{2}$ Although these figures do not reveal the high degree of heterogeneity that exists from department to department and from retail company to retail company, what they do indicate is that PLs have become an inescapable part of what is on offer in supermarkets.

\section{[Table 1 here ]}

The evolution of brands has been linked to the strategy adopted by the mass retailers to compete more and more directly with National Brands (NB) in terms of quality. The strategy initially adopted, which rested exclusively on price-based competition (Carrefour's "free products", 1976), has been abandoned in favor of competition based on two dimensions: prices and quality. ${ }^{3}$ One of the driving forces behind this evolution is tariff negotiation with the manufacturers of NBs. The introduction of high quality private label products constitutes a strategic threat to industrialists, causing them to lower their prices (Bontems, Monier and Réquillart, 1999; Caprice, 2000). The improvement in the quality of private brands has also been facilitated by a better control of the production costs of private label products (Mills, 1995; Bontems, Monier and Réquillart, 1999).

\footnotetext{
${ }^{2}$ This difference can be explained by the fact that PLs are sold at an average price that is lower than the average prices of the products displayed in the department.

${ }^{3}$ The "generic" brand was then attributed to low-quality products, which are less linked to the reputation of the retail store. These "generic" brands are used by the mass retail stores to slow down the growth of hard discount.
} 
The "quality" option led, in the 1990s, to the appearance on the market of "me too" retail brands. "Me too" wares represent the largest part of mass retailers' offering and through them retail companies offer products that are competitive both in terms of quality - the quality of these products is significantly higher than that of the first generation of private labels - and in terms of price: indeed, private label prices are on average $20 \%$ lower than those of NBs. Since the early 2000s, retail companies have developed a second quality based strategy through "upmarket" private label ranges for certain niche markets (emphasis on the qualities of the land where the goods are produced, on their flavours, etc). ${ }^{4}$ We shall call the standard private label SPL and the high quality private labels HPL. The objective of this study is to assess consumer perception of this two-faceted strategy adopted by the mass retail industry to compete with national brands. The second section presents an overview of some previous studies related to perception of PLs versus NBs. The third section is dedicated to the method and the fourth section to the data. In the fifth section, we present the results. The last section concludes.

\section{Background}

The questions related to consumer perception of PLs and to what motivates them to buy these labels have been the topic of much research work (for a review of the literature, BergèsSennou, Bontems and Réquillart, 2004). Studies using early 1990s data reveal that sociodemographic characteristics have an effect on the purchase of PLs. It was found that high incomes decrease the consumers' probability of buying a PL product (Richardson et al, 1996, Dhar and Hoch, 1997), while on the contrary the size of the household (Richardson et $a l, 1996)$ and the level of education (Binkley et al., 2001) have a positive influence on their probability of buying PLs. However, using more recent data, Cataluña, Garcia and Phau

\footnotetext{
${ }^{4}$ For example, the Leclerc group introduced a range called "Nos régions ont du talent"; Carrefour introduced a "Reflets de France" range and Casino has a "Destinations Saveurs" brand, etc. They correspond to the UK equivalents "Tesco's finest" or Sainsbury's "Taste the difference".
} 
(2006) or Bergès et al. (2009) conclude that socio-demographic variables have no strong influence on the purchase of PLs.

Experimental economics shows that NBs often enjoy an advantage over PLs in terms of perceived quality (Richardson, Dick and Jain, 1994; Kumar and Steenkamp, 2007). This advantage rests less on the intrinsic quality of the products - which, in blind tests, are often difficult to differentiate - than on reputation. Thus, these brands are for the most part differentiated vertically: given equal prices, the majority of consumers choose NBs over PLs. PLs are therefore chosen by consumers partly because of their price advantage. However, a number of studies put this price effect into perspective, showing that it varies from product to product: in some cases (orange juice), consumers remain loyal to the PL even when the price differential decreases (Livesey and Lennon, 1978). In the same vein, Baltas (1997) and Chardon and Dumartin (1998) indicate that buyers of PLs consider that the intrinsic quality of these PL products is satisfactory.

A consumer's preference for a NB over a PL is often related to the perceived purchasing risk (Batra and Sinha, 2000; Erdem, Zhao and Valenzuela, 2004). This parameter plays a significant role both at individual and at sector level. In the latter case, it partly explains why the penetration rate of PLs varies according to the nature of products: high in the case of some staple goods (UHT milk, pasta products, etc...) but low in the case of products for which consumer trust is absolutely essential (baby food, cosmetics). This characteristic certainly contributes to lowering consumers' price sensitivity for the benefit of NBs. Nevertheless, it varies from individual to individual and from product to product and should logically decrease with the improvement of the intrinsic quality of PL products and their increasing availability.

Indeed, results vary according to the period studied and to the establishment of the PLs. In a study of the American orange juice market in the early 1990s, Binkley et al (2001) find that NBs have lower price elasticity than PLs, especially in the case of the upmarket segment of 
refrigerated orange juice. Conversely, in a more recent study about pasta products in France sold by a famous retailer - where PLs are more strongly established than on the American market - Bergès, Hassan and Monier-Dilhan (2009) observe that consumers' willingness to pay for a PL product is higher than their willingness to pay for the leading NBs.

\section{Method and Data}

Part A focuses on the methodological choices intended to measure consumers' attachment to brands. Part B lists the products and the retailers involved in the analysis and presents the data used. Part C explains the demand model (AIDS).

\section{A Demand price elasticity: a measure of consumers' attachment to brands}

This paper aims to compare consumers' global attachment to NBs and PLs. We capture the attachment to brands throughout the own-price elasticities of demand. The own-price elasticity of demand for a given good measures consumers' reactions to the price variations of that good in terms of purchased quantity : The stronger the consumers' attachment to the product, the lower the variation in the demand to price variations and the weaker the demand price elasticity (in absolute value).

Marketing researchers (Merunka, Changeur and Bourgeat, 1999) question the ability of demand price elasticities to measure consumer loyalty to products. They point out that demand variations may occur not only in reaction to prices: For example, they can translate a reduction of the shelf space devoted to the product by the retailer. Nevertheless, such risk is reduced when the number of retailers taken into account increases or the period of time is extended.

Another concern is whether the brand elasticities hierarchy provides a good picture of that of consumers' attachment to brands. This question comes down to the relationship 
existing between perceived quality and demand price elasticity. Theoretical studies have examined the question from the supply viewpoint (for a review of the literature, see Coibion, Einav and Hallav, 2007). These studies endeavour to determine the conditions under which a firm offering two qualities can gain higher profit margins with its "upmarket" products - not only in absolute but also in relative value - than with its generic quality products . In their pioneering study, Mussa and Rosen (1978) analyse the behaviour of a monopoly firm offering two qualities differentiated according to a price sensibility parameter. They show that although the profit margins associated with the high quality goods are, in absolute value, higher that those of the generic quality products, their relative value is lower.

Reopening Mussa and Rosen's analysis (1978), Verboven (1999) finds in a context of duopoly the demand price elasticity of the high quality shorter, in absolute value, than that of the generic quality. According to Verboven, two elements can lead to lower elasticities for the upmarket product: the attachment of the consumers to brands selling high quality products (advertising) and the ability of enterprises to make the information about high quality products' prices costly for the consumer. In the context of the competition between NBs and PLs, let's notice that if the former favours NBs, the latter must benefit PLs. Indeed, comparing prices between retail companies is easier in the case of NB products, the characteristics of which do not vary from one retailer to the next, than it is in the case of PL products which are designed by the retailer.

Most empirical studies on the demand for differentiated goods find that direct price elasticities are lower for "high quality" products. Investigating the beer market, Hausman, Leonard and Zona (1994) explained this finding by the fact that consumers of high quality products are less sensitive to prices than other consumers with lower incomes. On the American automobile market, Berry, Levinsohn and Pakes (1995) found also that upmarket cars had the lowest direct price elasticity of demand. Nevertheless, in this example, the 
highest elasticities are not necessarily associated with the cheapest cars. They are observed for goods on the intermediary segment, i.e. goods the supply of which is the densest. Before presenting the model used to compute price elasticities, we describe the data used.

\section{B The Data}

Contrary to some previous papers (Binkley et al., 2001 or Bergès, Hassan and Monier-Dilhan, 2009), the present investigation does not rely on a single example (one product sold by one retailer). To bring out more basic features, several products are considered (tree products, see below). Moreover, as PLs are retailer-dependent in terms of many parameters (quality, packaging, price, date at which the product was introduced on the shelves, etc...), it is useful to consider several retailers. This study incorporates three of the five largest French mass distributors.

The economic data we have used here are drawn from the TNS Worldpanel database. This database comes from a panel of approximately 10,000 households where consumers home scan their purchases and thus provide information on value and quantity of food products bought as well as where the products were purchased, their brand, their price and other information about the offer variables (the characteristics of the product, possible promotional campaign, etc).

The high-quality private labels were recently introduced. In the TNS World Panel database, the year 2004 is one of the first years in which upmarket private labels appear for a significant number of products and retail companies. The analysis shall therefore focus on the 2004-2005 period and on three staple products: pasta, biscuits and jam. These three products comply with the double constraint related to their existence and numerous purchases. Indeed, for each retail group and each product, it is necessary to observe both a standard private label and a high-quality private label. Moreover, the number of purchases must be high enough to 
estimate a demand system while ensuring that the important problem related to the nonpurchase of some commodities be prevented.

PLs being by definition specific to each retailer, we have distinguished three retail companies. This choice was determined by their weight in the mass food retail industry : These three retail groups represented in $200745 \%$ of the cumulated sales of food products. This choice also takes into account diversities in terms of PLs positioning, of communication on this market section and of possible historical advantage.

For each retail group, we have distinguished various categories of offer:

- The leading National Brands (NBs): this category comprises the three national brands with the largest market shares. ${ }^{1}$

- The standard private labels (SPL): these are the "me-too" products competing directly with NB products.

- The high-quality private labels (HPL): these are the retailers' own products sold under niche private labels at prices that are mostly higher than those of the equivalent NB products.

- The other national brands $(O N B)$ : this category is composed of branded products which are neither NBs nor the lowest price products. They are generally upmarket niche products. $^{2}$

- The low price products (LP): this category includes the cheapest generic products offered by each retailer. They are sold at lower prices than those of SPL and are supposed to compete with products offered by hard discount retailers.

Table 2 indicates, for each product and each retail group, the market share in volume as well as the average price (and standard deviation) for each category of goods.

\footnotetext{
${ }^{1}$ These are Lustucru, Barilla and Panzani for pasta; LU, BN and Delacre for biscuits, and Confipote, Bonne Maman and Andros for jam.

${ }^{2}$ Croix de Savoie for pasta, Balhsen for biscuits, or Chivers for jam.
} 


\section{[Table 2 here ]}

We note a high level of price competition between retailers within the NB segment, whatever the product. This is also the case for the various retailers' SPL products, but not for HPL. On average, the price difference between the NBs and the SPL is $36 \%$ for pasta products, $23 \%$ for biscuits and $30 \%$ for jam products. Inversely, the prices of NBs are lower than those of HPL by $30 \%$ to $40 \%$, with some exceptions, however, depending on the product. On the other hand, the prices of HPL products are close to those of ONB products, with which they compete in the high quality segment. The different products therefore reflect the segmentation according to prices implemented by large retailer groups. We observe first the low-price products, then the standard private labels, followed by the leading NBs and finally the "up-market" private label products and the other NBs.

In 2004-2005, the NBs dominated the market, either in absolute (they accounted for over $60 \%$ of the pasta market shares) or in relative value, with market shares ranging from $35 \%$ to $48 \%$ for biscuits and jam products respectively. SPL only take the dominant position in 1 case out of 9 (jam sold by retailer 2). The assortment of SPL slightly varies from one retailer to the next, but it does vary more significantly from product to product, with a very high degree of presence in the case of jam. The market shares of SPL range between $16 \%$ (pasta in retailer 3) and 31.5\% (biscuits, retailer 1). In 2004-2005, HPL were still niche products, with a market share of $4.5 \%$ on average. Retailer 2 is at the forefront of the distribution of this kind of product, and jam products constitute, as for SPL, the most favorable segment to HPL products. The market shares held by the "low-price" products and the heterogeneous group of other national brands are non negligible (on average $7.3 \%$ and $12 \%$ respectively) but vary significantly from product to product and from one retailer to the next. 
Distinguishing the different retailers and products, we calculate the price elasticities for the five kinds of product categories we have identified.

\section{C The Demand Model (AIDS)}

Elasticities are computed using the estimated parameters of an Almost Ideal Demand System (AIDS; Deaton and Muelbauer, 1980). In the last two decades, this model has been widely used in research studies on the demand for food products (see among others Eales and Unnevehr, 1988; Moschini and Mielke, 1989; Moschini, Moro and Green, 1994; Eales and Henderson, 2001). Like other demand systems (Translog, Rotterdam...), AIDS is both flexible and computationally easy to estimate. Moreover, since it does not start from some arbitrary preference system but from a specific class of preferences (PIGLOG) which permits exact aggregation over consumers, AIDS makes it possible the representation of market demands as if they were the outcome of decisions by a rational representative consumer.

A limitation of demand models is they cannot include a high number of alternatives, the number of cross price elasticities growing exponentially with the number of products. This limitation can however be overcome thanks to the weak separability hypothesis. This makes it possible to model budget allocation decision like a sequential choice process. Only the choices between products belonging to the same category are made simultaneously. For staple food products, this model seems acceptable: the consumer buys these products regularly without really making a choice between these and other expenses. Once s/he has made the decision to purchase a product, s/he then chooses the brand: In the present study, we are interested in the second stage of the choice process. Moreover, demand systems allow for the purchase of variable quantities of each product. In the case of low-price everyday products, this feature is more suitable than the assumption of a unitary demand specific to choice models (more adapted to durable expensive goods such as automobiles, see Pinkse and Slade, 
2004).

The households panel is representative of the French population in income and profession, and the data are rich and wide in terms of information. Therefore, we can aggregate individual data for 2004 and 2005 on a weekly time path to observe the purchasing behavior of a (composite) national representative consumer. For each product and each retailer, we thus have a series of 104 observations, including in particular the total expense on the product considered, its distribution between the different brands, and retail prices. We also introduce a variable reflecting promotional intensity. Indeed, promotions can influence the budget decisions of the representative consumer. Since we observe the final decision of consumers, part of the effect is therefore already integrated into the data, whether they are price or quantity promotions. However, the promotional impact is not limited to this direct effect; it also relies on the announcement effect. The Promo variable is constructed from the item of information indicating, for each purchase, whether the household bought the product while it was on promotion. We then calculate for each week, for a given retailer and a given product, the distribution of the promotions between the 5 groups of brands. We denote Promo ${ }_{i}$ the promotion rate of product $i$ in relation to its competitors (thus, for each week, $\sum$ Promo $\left._{\mathrm{i}}=1\right)$. Promotions are present in all categories of products, though the promotion rate of HPL is low. Table 3 indicates the distribution of promotion rates per brand, retailer and product during the 2004-2005 period.

\section{[Table 3 here ]}

It is not surprising to observe that the promotion rates for NB and ONB products are identical among the various retailers because there are usually coordinated national campaigns. However, this rate is heterogeneous for SPL and to a lesser extent for HPL, depending on each retailer specific policy. 
The demand model takes the form of a system of equations written in the following way for each product and each retailer company:

$$
w_{i t}=\alpha_{i}+\sum_{j=1}^{5} \gamma_{i j} \log p_{i t}+\beta_{i} \log \left(Y_{t} / P_{t}\right)+\theta_{i} \operatorname{Promo}_{i t}+\rho_{i t}
$$

where the dependent variables are the weekly market share of each brand in the weekly budget of the representative household ( $w_{i t}$ with $i=1, \ldots, 5$ and $t=1, \ldots, 104$ ). Nine independent demand systems are estimated, one for each product sold in each retailer company.

The independent variables are the weekly prices of the 5 brands $\left(p_{i t}\right)$, the total expense for the product considered in the retail store studied $\left(Y_{t}\right)$, corrected by an index of average prices $\left(P_{t}\right)$ and $\rho_{i t}$ is the error term. The translog price index $P_{t}$ (where $\left.\log P_{t}=\alpha_{0}+\sum_{i} \alpha_{i} \log p_{i t}+\sum_{i}^{n} \sum_{j}^{n} \gamma_{i j} \log p_{i t} \log p_{j t}\right) \quad$ is, as suggested by Deaton and Muellbauer (1980), replaced by a linear approximation defined by the Stone index $\left(\log P_{t}=\sum_{i} w_{i} \log p_{i}\right)$. To overcome the simultaneity problem related to the presence of $w_{i t}$ in both terms of equation (1), $w_{i t}$ is substituted by the $w_{i}$ mean in the Stone index. We impose the theoretical restrictions of additivity of budget shares $\left(\sum_{i} \alpha_{i}=1\right)$, of homogeneity and of symmetry $\left(\sum_{i} \gamma_{i j}=\sum_{j} \gamma_{j i}=\sum_{i} \beta_{i}=0\right)$. Resulting from the additivity hypothesis, only four budget share equations are estimated. ${ }^{6}$ Furthermore, the prices and expenses are normalized by their means (Asche and Wessells, 1997).

The price elasticities (direct and cross) are then calculated from the coefficients estimated in the share regressions, using Green and Alston's tests (1990). The formulas for this calculation are the following:

\footnotetext{
${ }^{6}$ Using an iterative procedure ensures the independence of the results in relation to the omitted product (PraisWinsten regression in the Stata software).
} 
Direct price elasticity: $\varepsilon_{i}=-1+\frac{1}{w_{i}}\left(\gamma_{i i}-\beta_{i}\right)$

Cross price elasticity: $\varepsilon_{i j}=-1+\frac{1}{w_{i}}\left(\gamma_{i j}-\beta_{i} w_{j}\right)$

where $\varepsilon_{i}$ and $\varepsilon_{i j}$ denote the direct price elasticity of product $i$, and the cross price elasticity of $i$ in relation to the price of $j$, respectively. These elasticities are calculated at the mean value.

\section{Results}

For four categories of brands (NB, SPL, HPL and ONB), whatever the product and the retailer, the direct price elasticities are negative; they are nil for LP (see Table 4). The cross price elasticities are seldom significantly different from zero. In the short term, consumers therefore react to a price variation by adjusting their demand for the brand they normally purchase, but without turning to another brand. Binkley et al (2001) obtain the same result in the case of orange juice: direct price elasticities of NBs and PLs are significantly different from zero and the cross price elasticities are nil. The overall quality of the regressions is acceptable. We observe that the value of $\mathrm{R}^{2}$ is more linked to the product (they are higher for pasta and biscuits) than to the retailer. Furthermore, as the data is presented in the form of time series, we have ensured that the residuals are not strongly correlated. The results of the tests (Durbin Watson and Box and Pierce) lead us to accept the null hypothesis of no residual correlation. The short time lag (week) and the absence of seasonality related to the products studied explain why the residuals exhibit the characteristics of a random white noise.

\section{[ Table 4 here ]}

The elasticities of NBs and SPLs are often close to one whereas the elasticities with the lowest absolute value are related to the LP and ONB. On the other hand, HPL have a high price elasticity. 
The objective of this study being to capture the brand impact on own-price elasticities, we aim to check for other sources of variability, namely the heterogeneity of products and retailers. We therefore estimate the following hedonic equation where we regress the elasticity variable (45 observations) on three characteristics: brand, retailer and product:

$$
\varepsilon_{i j p}=\alpha+\sum_{i=1}^{I-1} \beta_{i} M_{i}+\sum_{j=1}^{J-1} \gamma_{j} E_{j}+\sum_{p=1}^{P-1} \mu_{p} P_{p}+u_{i j p}
$$

where $\varepsilon_{i j p}$ is the direct price elasticity of product $p$ sold under brand $i$ at retailer $j$. Dummy variables are created to isolate the brand effect $(M)$, the retailer effect $(E)$ and the product effect $(\mathrm{P})$.

The reference good used is the product "LP pasta sold by retailer 1". The regression results are presented in Table 5. Note that to calculate the expected values for each elasticity, one must add to the elasticity of the reference good measured by the constant $(-0.58)$, the values associated with the characteristics concerned. For example, the expected elasticity for SPL biscuits sold in retail shop 2 is equal to -1.21 .

\section{[Table 5 here ]}

All direct price elasticities are negative. This result also applies in the case of biscuits despite the positive coefficient associated with this product. A mean test shows that the direct price elasticities do not differ according to the retailers (the coefficients associated with retailers 2 and 3 are not different from zero). Similarly, the product effect is limited to biscuits whose elasticity is half a point lower than that of other products.

Contrary to the most common hypothesis, the demand for SPL is not more elastic to prices than the demand for NBs. A mean-test of equality shows that the gap between the two coefficients is indeed not significant. The reactions of buyers to variations in the prices of both types of brands exhibit comparable levels of intensity (in both cases, the elasticity is 
close to one): when there is a price increase, the demand for PLs does not decrease more than the demand for NBs. In other words, consumers' attachment to PL and NB is therefore the same. This conclusion is contrary to that of Binkley et al (2001) who show that SPL had a more fragile position on the American market in 1991.

This evolution can be explained by the rise in the perceived quality of SPL (intrinsic quality, packaging, shelf space) and by a learning effect among consumers. The latter has increased consumers' loyalty to PLs, which has reinforced their attachment to the brand by avoiding the extrinsic cue premium. According to Tourtoulou, Dietsch and Krémer (2000), advertising for a brand results in a fall in direct price elasticity. This phenomenon clearly indicates an attachment by the consumer to this brand. For SPL products, a similar phenomenon occurs with consumer loyalty to a retailer. Bergès and Orozco (2009) show that when households have a choice between 6 different retail stores, all located within a $20 \mathrm{~km}$ radius, they shop in 3 retail stores on average; furthermore, a large percentage of households are characterized by a high index of store loyalty. These elements also contribute to consumers' attachment to PLs.

However, note that the highest elasticities in absolute value are those related to HPL. The introduction of these upmarket retailers' brands on store shelves is recent: their reputation must therefore develop and product maturity has not been reached yet. The elasticity values of HPL must be compared with the direct price elasticities of other national brands, positioned on the same segment in terms of quality and specificity (organic products, products with a registered designation of origin...). The demand for these products is not elastic to prices. This segment comprises the high quality national brands (the distribution of which is not as widespread as that of the better known leading national brands), commercializing niche products which are close in characteristics to those sold in the delicatessen sections of the retail stores. The demand for this type of product is probably associated with a low price 
sensitivity and a high perceived quality. Consumers do not yet perceive HPL products as close substitutes for ONB products.

\section{Conclusion}

The introduction by retailers of their own private labels has been an important stage in the attempts by the mass distribution industry to gain a dominant position as an economic actor. Indeed, they have enabled this sector to go beyond its retail function and to gain the status of manufacturer. These private labels have shifted the balance of power from the manufacturers of national brands to the retail groups. What is more, private labels represent for mass retailers a direct source of profit increase as the margins on SPL products are known to be $20 \%$ higher on average than those gained on other products, and they reinforce consumers' store loyalty (Bonfrer and Chintagunta, 2004).. Our results indeed show that in the last few years, these products have gained the loyalty of consumers by reducing the buyers' sensitivity to prices and by increasing their market shares. With respect to HPL, which represent a strategy implemented more recently by the mass distribution industry, the market shares are already significant, if we bear in mind that the first objective of this strategy is to assert the presence of the mass distribution sector on the segment of high quality products. The high quality products supporting this strategy do not necessarily yield high profits, nor do they achieve high market shares (Randall, Ulrich and Reibstein, 1997). The balance of power between HPL and ONB products within retail stores in 2005 is comparable to that observed in the 1990s between SPL and NB products. The notoriety of what we have called ONB (Other national brands) products is greater than that of the upmarket private labels: consumers do not hesitate to pay a little more to keep buying the same product. However, it is reasonable to believe that the situation is not set in stone and that the selling power of retailers is sufficient to positively influence consumers' perception of and attachment to HPL products. 
In addition to the standard segment and upmarket one, the distribution network develops low prices. Direct competitors of such products are hard discount retailers. The purpose of this research is to study the competition between NB/PL within the mass food retail sector. The hard discount stores are not included in the analysis, which does not allow a relevant study of the role of first price products. Until recent years, competition between national brands and private labels took place moderately on the standard quality segment. Large retailers are now expanding their own brand strategy in the high quality segment, whose market share is significant because it represents approximately $15 \%$ (HPL $+\mathrm{ONB})$.

In the future, competition among brands of large retailers will therefore cover the full spectrum of quality from the lowest price (in order not to lose market share relatively from hard discount) to high quality products.

Acknowledgments: Many thanks to Valérie Orozco (TSE, GREMAQ-INRA) for her engineering help with the data. 


\section{References}

Asche F. and Wessells C.R., 1997, On price indices in the almost ideal demand system, American Journal of Agricultural Economics, 79, 1182-1185;

Baltas, G. (1997), Determinants of store brand choice: a behavioral analysis, Journal of Product and Brand Management, 6(5), 315 - 324.

Batra, R. and Sinha Indrajit (2000), Consumer-Level Factors Moderating the Success of Private Label Brands across Product Categories, Journal of Retailing, 76 (2), 175 - 191.

Bergès F., Hassan, D. and Monier-Dilhan, S. (2009), Consumers' decision between private labels and national brands in a retailer's store, Gestion 2000, Vol. 3, mai-juin, p. 41-57

Bergès F. and Orozco V. (2009), "Statistical indexes and economic analysis for store and brand loyalty in France", mimeo;

Bergès-Sennou, F., P. Bontems, and V. Réquillart (2004). Economics of Private Labels: a Survey of Literature, Journal of Agricultural \& Food Industrial Organization, Vol. 1(3). Available at http://www.bepress.com/jafio/vol2/iss1/art3

Berry Steven, Levinsohn James and Pakes Ariel, 1995, Automobile Prices in Market Equilibrium, Econometrica, 63(4), 841-890;

Binkley , J. Eales, M. Jekanowski and R. Dooley. (2001) Competitive Behavior of National Brands: The Case of Orange Juice. Agribusiness, Vol. 17(1), 139-160.

Bonfrer, A., and P.K. Chintagunta (2004). Store brands: who buys them and what happens to retail prices when they are introduced?, Review of Industrial Organization, 24, 195-218. 
Bontems, P., S. Monier, and V. Réquillart (1999). Strategic effects of private labels, European Review of Agricultural Economics, 26, 147-65.

Caprice S., 2000. Contributions à l'analyse de la puissance d'achat dans les relations verticales : interactions stratégiques et marques de distributeur, Thèse Université Paris I, 280 pages.

Cataluña F., Garcia A. and Phau I. (2006) “The Influence of Price and Brand Loyalty on Store Brands Versus National Brands" International Review of Retail, Distribution and Consumer Research, Vol. 16, N) 4, 433-452

Chardon O. et Dumartin S., 1998. Fidélité aux enseignes, fidélité aux marques : le choix des consommateurs. INSEE Première, $\mathbf{n}^{\circ} \mathbf{6 0 9}$.

Coibion Olivier, Einav Liran and Hallak Juan Carlos, 2007. Equilibrium demand elasticities across quality segments, International Journal of Industrial Organization, 25(1), 1330 ;

Deaton, A. and Muellbauer J., 1980, An Almost Ideal Demand System, American Economic Review, Vol. 70, 312-336;

Dhar S. K. and S.J. Hoch (1997), Why Store Brand Penetration Varies by Retailer?, Marketing Science, 16(3), 208 - 227.

Eales J. and Henderson Jason R., 2001, The impact of negativity on separability testing, American Journal of Agricultural Economics, 83(2), 465-477.

Eales J. and Unneverh L.,1988, Demand for Beef and Chicken Products: Separability and Structural Change, American Journal of Agricultural Economics, 70(3), 521-532; 
Erdem T., Y. Zhao and A. Valenzuela (2004), Performance of Store Brands: a CrossCountry Analysis of Consumer Store Brand Preferences, Perceptions and Risk, Journal of Marketing Research, Vol. XLI, 86 - 100.

Frank R. E. and H. W. Boyd (1965), Are Private-Brand Prone Grocery Customers Really Different?, Journal of Marketing Research, 2(4), 27 - 35.

Green R., Alston JM (1990), Elasticities in the AIDS Model American Journal of Agricultural Economics 72, 442-44;

Hausman J., Leonard G. and Zona J.D. (1994), Competitive analysis with differentiated products, Annales d'Economie et de Statistique, 34, 159-180;

Kumar and Steenkamp, (2007), Private Label Strategy: How to meet the Store Brand Challenge, Harvard Business School Press, 270 pages.

Livesey F. and P. Lennon (1978), Factors Affecting Consumers' Choice, European Journal of Marketing, 12(2), 158 - 170.

Merunka D., Changeur S. and Bourgeat P. (1999), "Models of Brands Competition: Practice and Limitations", Recherches et Applications en Marketing, Vol. 14, n4/99, 2:7

Mills, D.E., 1995. Why retailers sell private labels. Journal of Economics and Management Strategy, 4(3), 509-528.

Moati Ph. (2008), L'envol des marques de distributeurs : une opportunité pour beaucoup d'industriels, Consommation et Modes de vie. Mai 2008, CREDOC.

Moschini G. and Mielke J. D. ,1989, Modeling the pattern of structural change in U.S. meat demand, American Journal of Agricultural Economics, 71, 253 - 261 ; 
Moschini G., Moro D. and Green R., 1994, Maintaining and testing separability in demand systems, American Journal of Agricultural Economics, 76, 61-73;

Mussa M. and Rosen S. (1978), Monopoly and Product Quality, Journal of Economic Theory, Vol. 18, 301 - 317;

Pinkse J. and Slade M. ,2004, Mergers, brand competition, and the price of a pint, European Economic Review, 48(3), 617-643;

Randall T., Ulrich K. and Reibstein D., 1997, Vertically Extending your Brand Has Impact on your Sales, but also on your Brand's equity, Marketing Science, 4, 356-379;

Richardson P. and A. Jain (1996), Household Store Brand Proneness: A Framework, Journal of Retailing, Summer, 72(2), 159 - 186.

Richardson P., Dick A. and Jain A. (1994), Extrinsic and intrinsic cue effects on perceptions of store brand quality, Journal of Marketing, Vol. 58, October, 28-36;

Tourtoulou, M. Dietsch, F. Krémer, 2000, Les déterminants de l'élasticité au prix des marques, Recherche et Applications en Marketing, 15(3), 43-53;

Verboven F., (1999), Product line rivalry and market segmentation with an application to automobile optional engine pricing, Journal of Industrial Economics, 47(4), 399-425; 


\section{Tables}

Table 1 : Market shares, in volume and in value,

of Private Labels in the mass food retail sector in France.

\begin{tabular}{|c|c|c|}
\hline Year & $\begin{array}{c}\text { Market share - } \\
\text { volume }\end{array}$ & Market share - value \\
\hline 1993 & 17 & na \\
\hline 1996 & 20 & na \\
\hline 2000 & 24 & 20 \\
\hline 2005 & 32 & 25 \\
\hline 2007 & 34 & 29 \\
\hline \multicolumn{2}{|c|}{ Source $:$ ANielsen in PLMA 2007. } \\
\hline
\end{tabular}

Page 22 
Table 2: Retail Group: Descriptive statistics, period 2004-2005 period

\begin{tabular}{|c|c|c|c|c|c|c|c|c|c|c|}
\hline \multirow[b]{2}{*}{$\begin{array}{l}2004- \\
2005\end{array}$} & \multicolumn{2}{|c|}{ NB } & \multicolumn{2}{|c|}{ SPL } & \multicolumn{2}{|c|}{ HPL } & \multicolumn{2}{|c|}{ ONB } & \multicolumn{2}{|c|}{$\mathbf{L P}$} \\
\hline & $\begin{array}{c}\text { Market } \\
\text { Share } \\
\%\end{array}$ & $\begin{array}{c}\text { Price } € \\
\text { (standard } \\
\text { deviation) }\end{array}$ & $\begin{array}{c}\text { Market } \\
\text { Share } \\
\%\end{array}$ & $\begin{array}{c}\text { Price } € \\
\text { (standard } \\
\text { deviation) }\end{array}$ & $\begin{array}{c}\text { Market } \\
\text { Share } \\
\%\end{array}$ & $\begin{array}{c}\text { Price } € \\
\text { (standard } \\
\text { deviation) }\end{array}$ & $\begin{array}{c}\text { Market } \\
\text { Share } \\
\%\end{array}$ & $\begin{array}{c}\text { Price } € \\
\text { (standard } \\
\text { deviation) }\end{array}$ & $\begin{array}{c}\text { Market } \\
\text { Share } \\
\%\end{array}$ & $\begin{array}{c}\text { Price } € \\
\text { (standard } \\
\text { deviation) }\end{array}$ \\
\hline \multicolumn{11}{|c|}{ Pasta } \\
\hline $\begin{array}{c}\text { Retailer } \\
1\end{array}$ & 60.5 & $\begin{array}{c}1.73 \\
(0.08)\end{array}$ & 27.6 & $\begin{array}{c}1.05 \\
(0.07)\end{array}$ & 2.6 & $\begin{array}{c}3.14 \\
(0.18)\end{array}$ & 9 & $\begin{array}{c}3.00 \\
(0.46)\end{array}$ & 0.3 & $\begin{array}{c}0.82 \\
(0.17)\end{array}$ \\
\hline $\begin{array}{c}\text { Retailer } \\
2\end{array}$ & 60 & $\begin{array}{c}1.74 \\
(0.16) \\
\end{array}$ & 18.6 & $\begin{array}{c}1.18 \\
(0.87)\end{array}$ & 10.1 & $\begin{array}{c}2.70 \\
(0.12) \\
\end{array}$ & 8.9 & $\begin{array}{c}2.90 \\
(0.31) \\
\end{array}$ & 2.4 & $\begin{array}{c}0.50 \\
(0.05) \\
\end{array}$ \\
\hline $\begin{array}{c}\text { Retailer } \\
3\end{array}$ & 65 & $\begin{array}{c}1.70 \\
(0.09)\end{array}$ & 16 & $\begin{array}{c}1.06 \\
(0.03)\end{array}$ & 4.3 & $\begin{array}{c}2.55 \\
(0.16)\end{array}$ & 9.7 & $\begin{array}{c}2.76 \\
(0.28)\end{array}$ & 4.3 & $\begin{array}{c}0.49 \\
(0.01)\end{array}$ \\
\hline \multicolumn{11}{|c|}{ Biscuits } \\
\hline $\begin{array}{c}\text { Retailer } \\
1\end{array}$ & 42.3 & $\begin{array}{c}5.04 \\
(0.41)\end{array}$ & 31.5 & $\begin{array}{c}2.74 \\
(0.26)\end{array}$ & 1.1 & $\begin{array}{c}5.85 \\
(1.46)\end{array}$ & 20.4 & $\begin{array}{c}6.70 \\
(0.62)\end{array}$ & 4.7 & $\begin{array}{c}2.80 \\
(0.33)\end{array}$ \\
\hline $\begin{array}{c}\text { Retailer } \\
2 \\
\end{array}$ & 40 & $\begin{array}{c}5.00 \\
(0.43) \\
\end{array}$ & 19 & $\begin{array}{c}4.36 \\
(0.45) \\
\end{array}$ & 1.8 & $\begin{array}{c}9.50 \\
(1.32) \\
\end{array}$ & 19.5 & $\begin{array}{c}7.39 \\
(0.47) \\
\end{array}$ & 18.7 & $\begin{array}{c}2.01 \\
(0.23) \\
\end{array}$ \\
\hline $\begin{array}{c}\text { Retailer } \\
\mathbf{3} \\
\end{array}$ & 42 & $\begin{array}{c}4.68 \\
(0.30) \\
\end{array}$ & 17.4 & $\begin{array}{c}4.13 \\
(0.30) \\
\end{array}$ & 2.6 & $\begin{array}{c}7.39 \\
(1.12) \\
\end{array}$ & 17.3 & $\begin{array}{c}7.44 \\
(0.49) \\
\end{array}$ & 20.6 & $\begin{array}{c}1.94 \\
(0.13) \\
\end{array}$ \\
\hline \multicolumn{11}{|c|}{ Jam } \\
\hline $\begin{array}{c}\text { Retailer } \\
1\end{array}$ & 48 & $\begin{array}{c}3.84 \\
(0.15)\end{array}$ & 27 & $\begin{array}{c}2.80 \\
(0.15)\end{array}$ & 4.4 & $\begin{array}{c}6.13 \\
(0.16)\end{array}$ & 16 & $\begin{array}{c}6.33 \\
(0.81)\end{array}$ & 4.3 & $\begin{array}{c}1.26 \\
(0.16)\end{array}$ \\
\hline $\begin{array}{c}\text { Retailer } \\
2\end{array}$ & 35 & $\begin{array}{c}3.88 \\
(0.31) \\
\end{array}$ & 43 & $\begin{array}{c}2.79 \\
(0.27) \\
\end{array}$ & 8 & $\begin{array}{c}5.50 \\
(0.72) \\
\end{array}$ & 6.5 & $\begin{array}{c}6.96 \\
(1.62) \\
\end{array}$ & 7 & $\begin{array}{c}1.04 \\
(0.12) \\
\end{array}$ \\
\hline $\begin{array}{c}\text { Retailer } \\
3\end{array}$ & 42.6 & $\begin{array}{c}3.82 \\
(0.24)\end{array}$ & 30.4 & $\begin{array}{c}2.44 \\
(0.09)\end{array}$ & 5.2 & $\begin{array}{c}6.30 \\
(0.14)\end{array}$ & 18 & $\begin{array}{c}6.02 \\
(0.70)\end{array}$ & 3.7 & $\begin{array}{c}1.04 \\
(0.10)\end{array}$ \\
\hline
\end{tabular}


Table 3: Promotion rate per brand, product and retailer in 2004-2005.

\begin{tabular}{|c|c|c|c|c|c|c|}
\hline \multirow{2}{*}{$\begin{array}{l}\text { Presence of a } \\
\text { promotion } \\
2004-2005\end{array}$} & NB & SPL & HPL & ONB & $\mathbf{L P}$ & \multirow{2}{*}{$\begin{array}{l}\text { Average rate per } \\
\text { retailer }\end{array}$} \\
\hline & $\begin{array}{c}\text { Rate } \\
\text { Standard } \\
\text { deviation } \\
\end{array}$ & $\begin{array}{c}\text { Rate } \\
\text { Standard } \\
\text { deviation } \\
\end{array}$ & $\begin{array}{c}\text { Rate } \\
\text { Standard } \\
\text { deviation } \\
\end{array}$ & $\begin{array}{c}\text { Rate } \\
\text { Standard } \\
\text { deviation } \\
\end{array}$ & $\begin{array}{c}\text { Rate } \\
\text { Standard } \\
\text { deviation } \\
\end{array}$ & \\
\hline \multicolumn{7}{|c|}{ Pasta } \\
\hline Retailer 1 & $\begin{array}{l}26.2 \\
0.09\end{array}$ & $\begin{array}{l}42.3 \\
0.14\end{array}$ & $\begin{array}{l}8.51 \\
0.83\end{array}$ & $\begin{array}{l}22.2 \\
0.11\end{array}$ & $\begin{array}{c}0.7 \\
0.14\end{array}$ & 22.71 \\
\hline Retailer 2 & $\begin{array}{l}28.9 \\
0.15\end{array}$ & $\begin{array}{c}26 \\
0.14\end{array}$ & $\begin{array}{l}12.9 \\
0.93\end{array}$ & $\begin{array}{l}21.3 \\
0.13\end{array}$ & $\begin{array}{l}10.6 \\
0.10 \\
\end{array}$ & 13.46 \\
\hline Retailer 3 & $\begin{array}{l}21.6 \\
0.08\end{array}$ & $\begin{array}{l}12.32 \\
0.07\end{array}$ & $\begin{array}{c}25.41 \\
0.08\end{array}$ & $\begin{array}{c}26.07 \\
0.10\end{array}$ & $\begin{array}{c}14.58 \\
0.06\end{array}$ & 23.09 \\
\hline \multicolumn{7}{|c|}{ Biscuits } \\
\hline Retailer 1 & $\begin{array}{l}16.4 \\
0.09\end{array}$ & $\begin{array}{l}46.2 \\
0.10\end{array}$ & $\begin{array}{l}1.99 \\
0.02\end{array}$ & $\begin{array}{l}27.8 \\
0.11\end{array}$ & $\begin{array}{c}7.5 \\
0.06\end{array}$ & 18.57 \\
\hline Retailer 2 & $\begin{array}{c}14 \\
0.06\end{array}$ & $\begin{array}{c}11 \\
0.09\end{array}$ & $\begin{array}{c}0.8 \\
0.01\end{array}$ & $\begin{array}{l}24.8 \\
0.13\end{array}$ & $\begin{array}{l}49.5 \\
0.14\end{array}$ & 15.44 \\
\hline Retailer 3 & $\begin{array}{l}12.4 \\
0.04\end{array}$ & $\begin{array}{c}10 \\
0.05\end{array}$ & $\begin{array}{c}5.4 \\
0.03\end{array}$ & $\begin{array}{l}21.7 \\
0.07\end{array}$ & $\begin{array}{c}50 \\
0.08\end{array}$ & 19.44 \\
\hline \multicolumn{7}{|c|}{ Jam } \\
\hline Retailer 1 & $\begin{array}{c}22 \\
0.32\end{array}$ & $\begin{array}{l}28.8 \\
0.24\end{array}$ & $\begin{array}{c}7.5 \\
0.01\end{array}$ & $\begin{array}{l}19.8 \\
0.21\end{array}$ & $\begin{array}{l}22.8 \\
0.25\end{array}$ & 11.55 \\
\hline Retailer 2 & $\begin{array}{c}22 \\
0.31\end{array}$ & $\begin{array}{l}41.4 \\
0.32\end{array}$ & $\begin{array}{c}7.2 \\
0.20\end{array}$ & $\begin{array}{c}8 \\
0.14\end{array}$ & $\begin{array}{l}15.2 \\
0.20\end{array}$ & 13.44 \\
\hline Retailer 3 & $\begin{array}{l}25.3 \\
0.27\end{array}$ & $\begin{array}{l}31.4 \\
0.22\end{array}$ & $\begin{array}{c}7.9 \\
0.10\end{array}$ & $\begin{array}{c}29 \\
0.25\end{array}$ & $\begin{array}{c}2.5 \\
0.12\end{array}$ & 10.30 \\
\hline
\end{tabular}


Table 4: Price elasticities and quality of the regression

\begin{tabular}{|c|c|c|c|c|c|c|c|c|c|c|}
\hline \multirow[b]{2}{*}{ AIDS } & \multicolumn{2}{|c|}{ NB } & \multicolumn{2}{|c|}{ SPL } & \multicolumn{2}{|c|}{ HPL } & \multicolumn{2}{|c|}{ ONB } & \multicolumn{2}{|c|}{ LP } \\
\hline & $\begin{array}{c}\text { Price } \\
\text { elasticity } \\
\text { (standard } \\
\text { deviation) } \\
\end{array}$ & $\begin{array}{c}\mathrm{R}^{2} \\
\text { (adjusted) }\end{array}$ & $\begin{array}{c}\text { Price } \\
\text { elasticity } \\
\text { (standard } \\
\text { deviation) }\end{array}$ & $\begin{array}{c}\mathrm{R}^{2} \\
\text { (adjusted) }\end{array}$ & $\begin{array}{c}\text { Price } \\
\text { elasticity } \\
\text { (standard } \\
\text { deviation) } \\
\end{array}$ & $\begin{array}{c}\mathrm{R}^{2} \\
\text { (adjusted) }\end{array}$ & $\begin{array}{c}\text { Price } \\
\text { elasticity } \\
\text { (standard } \\
\text { deviation) }\end{array}$ & $\begin{array}{c}\mathrm{R}^{2} \\
\text { (adjusted) }\end{array}$ & $\begin{array}{c}\text { Price } \\
\text { elasticity } \\
\text { (standard } \\
\text { deviation) }\end{array}$ & $\begin{array}{c}\mathrm{R}^{2} \\
\text { (adjusted) }\end{array}$ \\
\hline \multicolumn{11}{|c|}{ Pasta } \\
\hline Retailer 1 & $\begin{array}{c}-1.01^{\star *} \\
(0.11)\end{array}$ & 0.42 & $\begin{array}{c}-0.74^{\star \star} \\
(0.17)\end{array}$ & 0.43 & $\begin{array}{c}-1.84^{\star \star} \\
(0.62) \\
\end{array}$ & 0.48 & $\begin{array}{c}-0.54^{\star *} \\
(0.19) \\
\end{array}$ & 0.47 & $\begin{array}{c}2.38 \\
(2.63) \\
\end{array}$ & -- \\
\hline Retailer 2 & $\begin{array}{c}-1.36^{\star \star} \\
(0.08)\end{array}$ & 0.68 & $\begin{array}{l}-2.2^{\star \star} \\
(0.22)\end{array}$ & 0.72 & $\begin{array}{c}-2.56^{\star \star} \\
(0.58)\end{array}$ & 0.32 & $\begin{array}{c}-1.36^{\star *} \\
(0.25)\end{array}$ & 0.30 & $\begin{array}{l}-1.30 \\
(1.13) \\
\end{array}$ & -- \\
\hline Retailer 3 & $\begin{array}{c}-1.13^{\star \star} \\
(0.08)\end{array}$ & 0.62 & $\begin{array}{c}-2.31^{\star \star} \\
(0.41)\end{array}$ & 0.52 & $\begin{array}{c}-2.21^{\star *} \\
(0.64)\end{array}$ & 0.54 & $\begin{array}{c}-0.42^{\star \star} \\
(0.25) \\
\end{array}$ & 0.56 & $\begin{array}{c}-2.85^{\star \star} \\
(0.90)\end{array}$ & -- \\
\hline \multicolumn{11}{|c|}{ Biscuits } \\
\hline Retailer 1 & $\begin{array}{c}-0.87^{\star *} \\
(0.09)\end{array}$ & 0.57 & $\begin{array}{c}-0.94^{\star *} \\
(0.11)\end{array}$ & 0.49 & $\begin{array}{c}-1.25^{\star \star} \\
(0.30)\end{array}$ & 0.19 & $\begin{array}{c}-0.62^{* *} \\
(0.18)\end{array}$ & 0.41 & $\begin{array}{c}-0.08 \\
(0.48) \\
\end{array}$ & -- \\
\hline Retailer 2 & $\begin{array}{c}-0.99^{\star \star} \\
(0.11)\end{array}$ & 0.47 & $\begin{array}{c}-1.18^{\star \star} \\
(0.13)\end{array}$ & 0.54 & $\begin{array}{c}-2.23^{\star \star} \\
(0.55)\end{array}$ & 0.33 & $\begin{array}{c}-0.67^{* *} \\
(0.21)\end{array}$ & 0.5 & $\begin{array}{c}-0.56^{\star \star} \\
(0.15)\end{array}$ & -- \\
\hline Retailer 3 & $\begin{array}{l}-0.77^{* *} \\
(0.11)\end{array}$ & 0.58 & $\begin{array}{c}-0.90^{* *} \\
(0.18)\end{array}$ & 0.51 & $\begin{array}{c}-1.38^{* *} \\
(0.26)\end{array}$ & 0.29 & $\begin{array}{c}-0.63^{* *} \\
(0.18)\end{array}$ & 0.40 & $\begin{array}{c}-0.55^{\star *} \\
(0.16)\end{array}$ & -- \\
\hline \multicolumn{11}{|c|}{ Jam } \\
\hline Retailer 1 & $\begin{array}{l}-0.99^{\star *} \\
(0.22)\end{array}$ & 0.32 & $\begin{array}{c}-1.53^{* *} \\
(0.27)\end{array}$ & 0.26 & $\begin{array}{c}-3.37^{\star *} \\
(1.56) \\
\end{array}$ & 0.14 & $\begin{array}{c}-0.64^{* *} \\
(0.23)\end{array}$ & 0.22 & $\begin{array}{l}-0.05 \\
(0.61) \\
\end{array}$ & -- \\
\hline Retailer 2 & $\begin{array}{c}-1.76^{\star *} \\
(0.21)\end{array}$ & 0.34 & $\begin{array}{c}-1.28^{* *} \\
(0.14)\end{array}$ & 0.45 & $\begin{array}{c}-0.58 \\
(0.53)\end{array}$ & 0.36 & $\begin{array}{c}-0.82 \\
(0.28)\end{array}$ & 0.19 & $\begin{array}{l}-0.21 \\
(0.83)\end{array}$ & -- \\
\hline Retailer 3 & $\begin{array}{c}-1.25^{\star \star} \\
(0.17)\end{array}$ & 0.20 & $\begin{array}{c}-1.00^{\star *} \\
(0.24)\end{array}$ & 0.28 & $\begin{array}{l}-2.5^{\star *} \\
(0.88) \\
\end{array}$ & 0.32 & $\begin{array}{c}-0.73^{\star \star} \\
(0.19)\end{array}$ & 0.18 & $\begin{array}{c}0.17 \\
(0.95) \\
\end{array}$ & -- \\
\hline
\end{tabular}


Table 5: Linear regression of own price elasticity

\begin{tabular}{|c|c|c|}
\hline Variables & Coefficient & t-Student \\
\hline NB & -0.53 & -1.90 \\
\hline SPL & -0.75 & -2.67 \\
\hline HPL & -1.46 & -5.21 \\
\hline ONB & -0.12 & -0.43 \\
\hline Retailer 2 & -0.35 & -1.59 \\
\hline Retailer 3 & -0.29 & -1.32 \\
\hline Biscuit & 0.47 & 2.14 \\
\hline Jam & 0.14 & 0.65 \\
\hline Constant & -0.58 & -2.20 \\
\hline Adjusted R & \multicolumn{2}{|c|}{0.44} \\
\hline
\end{tabular}

Page 26 